\title{
Association between RANTES -403A/G polymorphism and susceptibility to hepatitis B virus infection: A meta-analysis
}

\author{
Xiaxia Zhang ${ }^{1}$, Beihong Liu' ${ }^{2}$, Binbin Wang ${ }^{2}$ and Zheng Zeng ${ }^{1}$ \\ ${ }^{1}$ Department of Infectious Diseases, Peking University First Hospital, Xicheng, Beijing 100034, China \\ ${ }^{2}$ National Research Institute for Family Planning, Haidian, Beijing 100081, China \\ Correspondence to: Zheng Zeng, email: zeng@bjmu.edu.cn \\ Binbin Wang, email: wbbahu@163.com
}

Keywords: RANTES; hepatitis B virus; meta-analysis; single nucleotide polymorphism

Received: May 27, $2017 \quad$ Accepted: October 14, $2017 \quad$ Published: January 11, 2018

Copyright: Zhang et al. This is an open-access article distributed under the terms of the Creative Commons Attribution License 3.0 (CC BY 3.0), which permits unrestricted use, distribution, and reproduction in any medium, provided the original author and source are credited.

\section{ABSTRACT}

The relationship between RANTES (regulated on activation, normal $T$ cell expressed and secreted) $-403 \mathrm{~A} / \mathrm{G}$ polymorphism and susceptibility to hepatitis B virus (HBV) infection were still controversial and unclear. This meta-analysis was performed to resolve this issue. After literature search, eight studies, comprising 2749 cases and 2753 controls, were collected and determined eligible for analysis. No significant association was found between the 403A/G A allele and persistent HBV infection $(O R=1.04,95 \% C I=0.96-1.13, P=0.34)$. By using subgroup analysis divided by ethnicity, significant association was found between the RANTES -403A/G gene polymorphism and susceptibility to HBV infection in the allele model for the Caucasian group $(O R=1.68,95 \% C I=1.38-2.04, P<0.001)$. In the genotype model, there was also a significant association between $-403 \mathrm{~A} / \mathrm{G}$ and the risk of HBV infection (AG versus GG: $O R=1.85,95 \% C I=1.42-2.41, P<0.001 ;$ AG+AA versus GG: $O R=1.75,95 \%$ CI $=1.35-2.26, P<0.001)$ among Caucasians. When using healthy individuals as controls, there were significant associations between the SNP and $\mathrm{HBV}$ infection (A versus $G$ : $O R=1.22,95 \% \mathrm{CI}=1.08-1.39, P=0.002 ; A G+A A$ versus GG: $O R=1.32,95 \% C I=1.12-1.56, P=0.001)$. When comparing the Han Chinese (CHB) and spontaneously recovered people, there was also a significant association ( $A$ versus $G$ : $O R=1.22,95 \% C I=1.08-1.37, P=0.002$ ). In conclusion, in the Caucasian population, the RANTES -403A allele is a risk factor of susceptibility to persistent HBV infection. The RANTES -403A/G polymorphism is likely to associate with the persistent infection of hepatitis $B$ virus, regardless of virus clearance. More studies are needed to validate this relationship.

\section{INTRODUCTION}

Hepatitis B virus (HBV) is still a severe challenge to the global public health, leading to over 400 million infections all over the world [1]. Approximately, 5-10\% of adult patients and $29-40 \%$ of child patients may not be able to clear HBV and will eventually progress into chronic hepatitis B (CHB) without elucidated mechanisms [2]. Many factors can lead to chronic HBV infection and further progress into cirrhosis and liver cancer, including host immune, viral replication level, genetics, HBV variants and others [3, 4].

RANTES (regulated on activation, normal $\mathrm{T}$ cell expressed and secreted) promotes the accumulation and activation of $\mathrm{CD} 4+\mathrm{T}$ cells, $\mathrm{CD} 8+\mathrm{T}$ cells, natural killer cells and dendritic cells (DCs), it is a powerful immune-regulatory chemokine in inflammatory disorders [5-7]. It acts as a ligand for CC receptor 5 (CCR5) that expressed on $\mathrm{T}$ cytotoxic cells, which were observed to be significantly decreased in CHB patients compared to healthy people [8]. Some studies have also suggested that the serum RANTES level in CHB patients was 
significantly elevated, suggesting a correlation with the progress of disease, but the specific mechanisms were not clear $[9,10]$. Recently, several polymorphisms of $R A N T E S$ have been reported to associate with the risk of $\mathrm{HBV}$ infection, including $-403 \mathrm{~A} / \mathrm{G},-28 \mathrm{C} / \mathrm{G}$ and $\mathrm{In} 1.1 \mathrm{~T}$ [11]. In Koreans, RANTES polymorphism at position $-403 \mathrm{did}$ not show any effect on increased HBV infection risk [12]. However, a significant association was observed between RANTES $-403 \mathrm{~A} / \mathrm{G}$ and the risk of HBV infection in Saudi population [13] as well as in North Americans [14].

The relationship between RANTES $-403 \mathrm{~A} / \mathrm{G}$ polymorphism and the risk of $\mathrm{HBV}$ infection are still controversial. The aim of this meta-analysis is to explore their relationship in a larger cohort.

\section{RESULTS}

A total of 35 relevant studies were selected for possible inclusion. Two of them were not performed in humans; seven studies were not focused on RANTES; four studies were vaccine related; eight were not casecontrol studies; one of them used the same dataset with a previous study; six studies did not analyze RANTES -403 polymorphism. According to our search strategy, eight case-control studies were eventually included in this meta-analysis [11-14, 17-20]. Specific selection process is displayed in the flow chart in Figure 1.

A total of 5502 individuals were curated in this metaanalysis of eight studies, including 2749 (49.96\%) patients with persistent HBV infection and 2753 (50.04\%) controls. Among the controls, 1256 were healthy individuals and 1497 were spontaneously recoveries (SRs) from HBV infection. All control individuals were in accordance with Hardy-Weinberg equilibrium. Two studies were of
Caucasians $[13,14]$; the others were focused on Asians $[11,12,17-20]$. However, two studies only presented the allelic data, our attempts of obtaining genotypic data from these two studies have failed. Therefore, we analyzed the allelic association between cases and controls from all the eight studies, and the genotypic association from six studies. The basic characteristics of eight studies are listed in Table 1.

The association between RANTES $-403 \mathrm{~A} / \mathrm{G}$ alleles and the risk of persistent $\mathrm{HBV}$ infection was shown in Figure 2. There was strong heterogeneity $\left(I^{2}=86.5 \%\right.$, $p=0.000$ at $-403 \mathrm{~A} / \mathrm{G})$, therefore we applied the randomeffects models. No significant association was found between RANTES -403A/G gene polymorphism and HBV infection in allelic model $(\mathrm{OR}=1.04,95 \% \mathrm{CI}=0.96-$ $1.13, p=0.34)$. The different genotypes : (a) AA versus $\mathrm{GA}: \mathrm{OR}=1.15,95 \% \mathrm{CI}=0.93-1.42, p=0.20$; (b) AA versus $\mathrm{GG}$ : $\mathrm{OR}=1.13,95 \% \mathrm{CI}=0.91-1.41, p=0.26$; (c) $\mathrm{GA}$ versus $\mathrm{GG}$ : $\mathrm{OR}=1.15,95 \% \mathrm{CI}=1.00-1.32, p$ $=0.05$; (d) $\mathrm{GA}+\mathrm{AA}$ versus $\mathrm{GG}$ : OR $=1.17,95 \% \mathrm{CI}=$ $1.03-1.34, p=0.02$, were shown in Figure 3.The GG genotype was potentially related to the decreased risk of HBV infection.

Subgroup analyses based on ethnicity was also performed. In the Caucasian population, the A allele was significantly associated with a higher risk of $\mathrm{HBV}$ infection $(\mathrm{OR}=1.68,95 \% \mathrm{CI}=1.38-2.04, P<0.001)$. Similarly, we also observed significant associations in different genotypic models (AG versus $\mathrm{GG}$ : $\mathrm{OR}=1.85,95 \% \mathrm{CI}$ $=1.42-2.41, P<0.001 ; \mathrm{AG}+\mathrm{AA}$ versus $\mathrm{GG}: \mathrm{OR}=1.75$, $95 \% \mathrm{CI}=1.35-2.26, P<0.001)$. However, in Asians, no significant association between the RANTES $-403 \mathrm{~A} / \mathrm{G}$ allele polymorphism and $\mathrm{HBV}$ infection were observed $(\mathrm{OR}=$ $1.05 ; 95 \% \mathrm{CI}=0.96-1.16, p=0.27$ ) (Table 2).

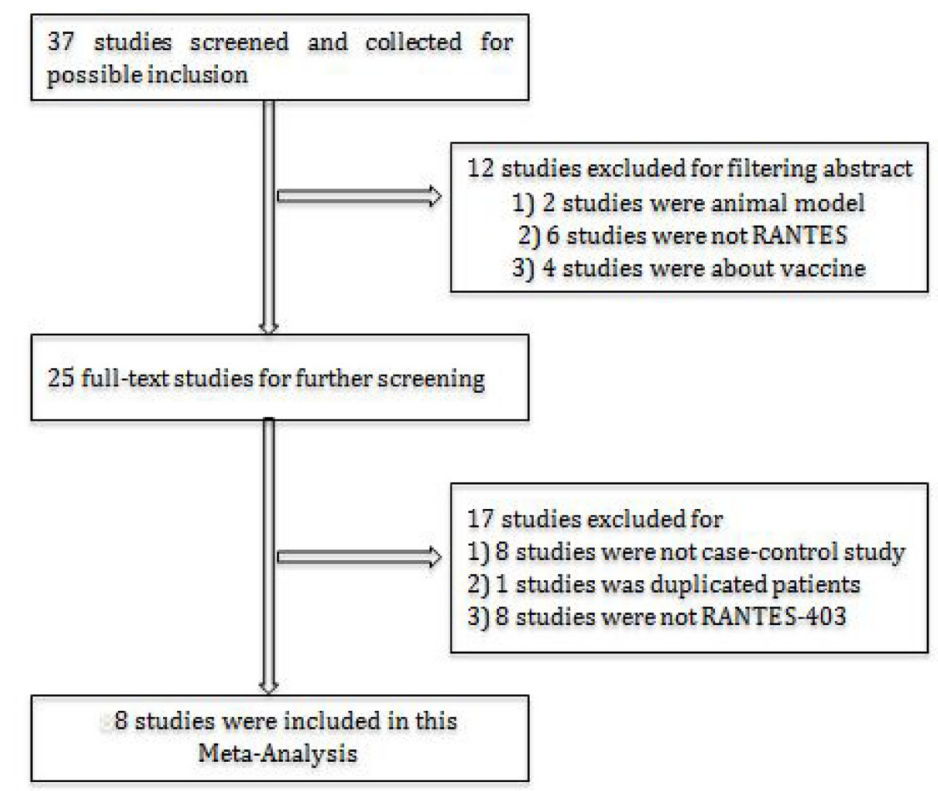

Figure 1: Flowchart of study selection in this meta-analysis. 
Table 1: The basic characteristics of eight articles in this meta-analysis about the relationship between RANTES-403 polymorphism and chronic $\mathrm{HBV}$ infection

\begin{tabular}{|c|c|c|c|c|c|c|c|c|c|c|c|c|c|c|}
\hline \multirow{2}{*}{ Author } & \multirow{2}{*}{ Year } & \multirow{2}{*}{ Ethnicity } & \multirow{2}{*}{ Cases } & \multirow{2}{*}{ Controls } & \multirow{2}{*}{ Control type } & \multicolumn{4}{|c|}{ Genotypes of cases } & \multicolumn{4}{|c|}{ Genotypes of controls } & \multirow{2}{*}{$\begin{array}{l}\text { Quality } \\
\text { (stars) }\end{array}$} \\
\hline & & & & & & G/A & GG & AG & $\mathbf{A A}$ & G/A & GG & $\mathbf{A G}$ & $\mathbf{A A}$ & \\
\hline Al-Qahtani & 2012 & Caucasian & 484 & 473 & Healthy & $710 / 258$ & 240 & 230 & 14 & $753 / 193$ & 299 & 155 & 19 & 5 \\
\hline $\begin{array}{l}\text { Chloe L. } \\
\text { Thio }\end{array}$ & 2008 & Caucasian & 181 & 316 & SR & $291 / 46$ & NR & NR & NR & $514 / 190$ & NR & NR & NR & 5 \\
\hline Heong JY & 2007 & Asian & 607 & 350 & SR & $750 / 464$ & 227 & 296 & 84 & $434 / 266$ & 128 & 178 & 44 & 7 \\
\hline $\begin{array}{l}\text { Sang Hoon } \\
\text { Ahn }\end{array}$ & 2006 & Asian & 349 & $106 / 243$ & Healthy/SR & $414 / 284$ & 128 & 158 & 63 & $415 / 283$ & $36 / 85$ & $55 / 118$ & $15 / 40$ & 6 \\
\hline DuanZP & 2005 & Asian & 152 & 139 & Healthy & 198/106 & 64 & 70 & 18 & $162 / 98$ & 52 & 58 & 20 & 5 \\
\hline Zhang C & 2012 & Asian & 229 & $200 / 161$ & Healthy/SR & $264 / 194$ & 82 & 100 & 47 & $406 / 316$ & $63 / 53$ & $100 / 74$ & $37 / 34$ & 6 \\
\hline $\begin{array}{l}\text { Byung Lae } \\
\text { Park }\end{array}$ & 2006 & Asian & 666 & 429 & SR & $755 / 535$ & NR & NR & NR & $508 / 346$ & NR & NR & NR & 6 \\
\hline $\begin{array}{l}\text { Hsiu-Ting } \\
\text { Tsai }\end{array}$ & 2012 & Asian & 102 & 347 & Healthy & $126 / 78$ & 42 & 42 & 18 & $538 / 156$ & 205 & 128 & 14 & 6 \\
\hline
\end{tabular}

SR: spontaneously recovered; NR: not reported. Quality: quality assessment according to the Newcastle-Ottawa Quality Assessment Scale.

We then stratified the controls into two types (healthy individuals $[11-13,18,20]$ and SRs $[12,14,17-$ 19]). We found that RANTES-403A allele was a risk factor of persistent $\mathrm{HBV}$ infection when compared to healthy controls (A versus $\mathrm{G}$ : $\mathrm{OR}=1.22,95 \% \mathrm{CI}=1.08-1.39$, $p=0.002 ;$ AG versus $\mathrm{GG}: \mathrm{OR}=1.29,95 \% \mathrm{CI}=1.09$ $1.54, P=0.004 ; \mathrm{AG}+\mathrm{AA}$ versus $\mathrm{GG}: \mathrm{OR}=1.32,95 \% \mathrm{CI}$ $=1.12-1.56, P=0.001)($ Table 3$)$. Interestingly, when individuals with $\mathrm{HBV}$ infection were combined with SR and compared with controls [11-13, 18, 20], we and found there was also a significant difference between the new case group and healthy controls (A versus $\mathrm{G}$ : $\mathrm{OR}=1.22$, $95 \% \mathrm{CI}=1.08-1.37, p=0.002$ ).

Sensitivity analysis was performed by removing individual study at one time. This analysis showed there was no influence of each study on ORs. Publication bias was assessed by Egger's linear regression test and funnel plot for the included studies. Figure 4 revealed that there

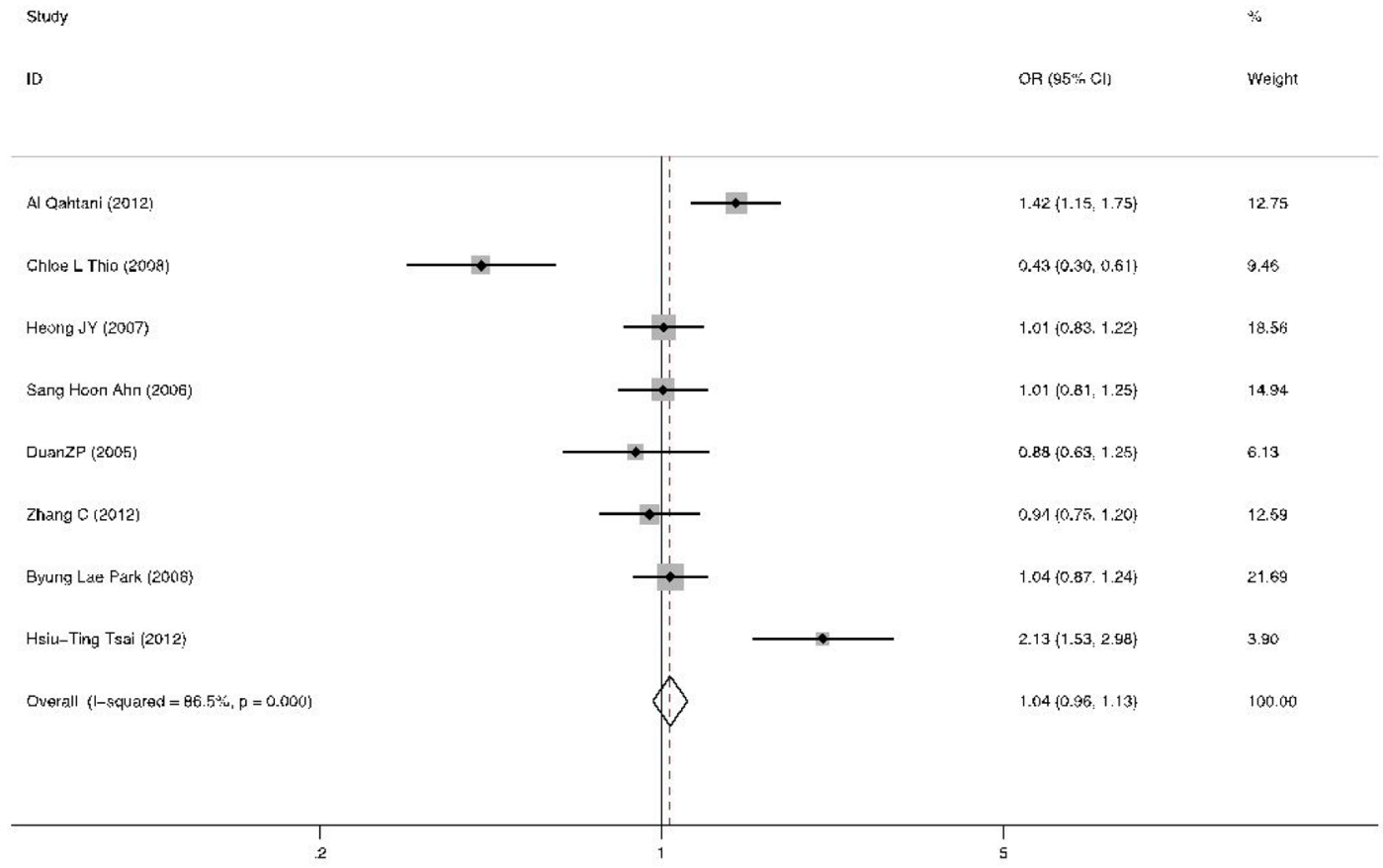

Figure 2: Forest plot of the risk of chronic HBV infection related to A allele versus $\mathrm{G}$ allele about $R A N T E S-403 A / G$ polymorphism in all studies. Black square means value of $\mathrm{OR}$, and the size of the square means inversely proportional to its variance. Horizontal line means 95\% confidence interval (CI) of OR. Black diamond means pooled results. 
is no evidence of obvious asymmetry of the funnel plots, indicating no significant publication bias existed in this meta-analysis (Egger's test $p=0.679$ ).

\section{DISCUSSION}

This is the first meta-analysis to investigate the relationship between the RANTES $-403 \mathrm{~A} / \mathrm{G}$ polymorphism and risk for $\mathrm{HBV}$ infection. Eight studies were collected following stringent inclusion criteria in order to validate the association between RANTES -403A/G polymorphisms and persistent $\mathrm{HBV}$ infection. We demonstrated the importance of the RANTES $-403 \mathrm{~A} / \mathrm{G}$ polymorphism in the HBV infection.

In the process of $\mathrm{HBV}$ infection, the immune system have a direct impact on the disease manifestation and outcome, which may induce hepatocellular damage [21]. The majority of adults with HBV infection may recover due to efficient immune response. The differences of immune mediators at the genetic level can influence the
A stosy

10

Nastion (2012)

Hosng JY [2007)

Seng Hoon Ahn (2006)

OugnZP (2006)

Zheng $C(2012)$

Heiz-Ting Tsei (2012)

Oweral (1-squered $=60 . \%, p=0.006)$
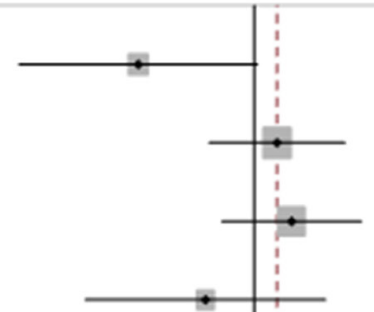

OR $(95 \%$ C $)$

$1.15(0.76,1.73)$

$1.25(0.82,1.01)$

$0.78(0.35,1.84)$

$1.15(0.74,1.79)$

$3.28(1.80,8.55)$

$1.15(0.20,1.42)$
$\%$

Weight

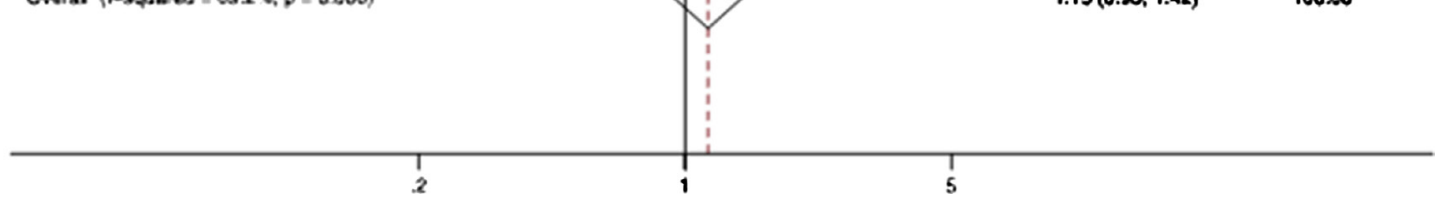

B suser

10

On (es:c)

Weight

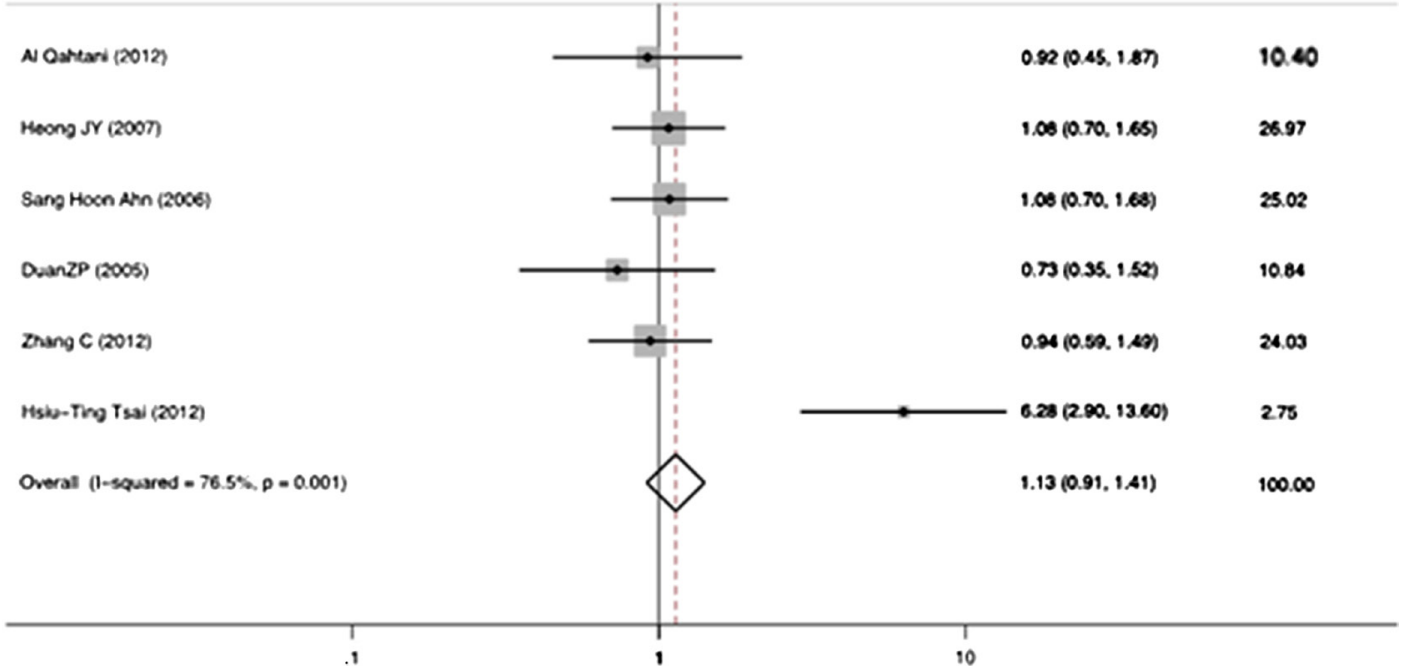




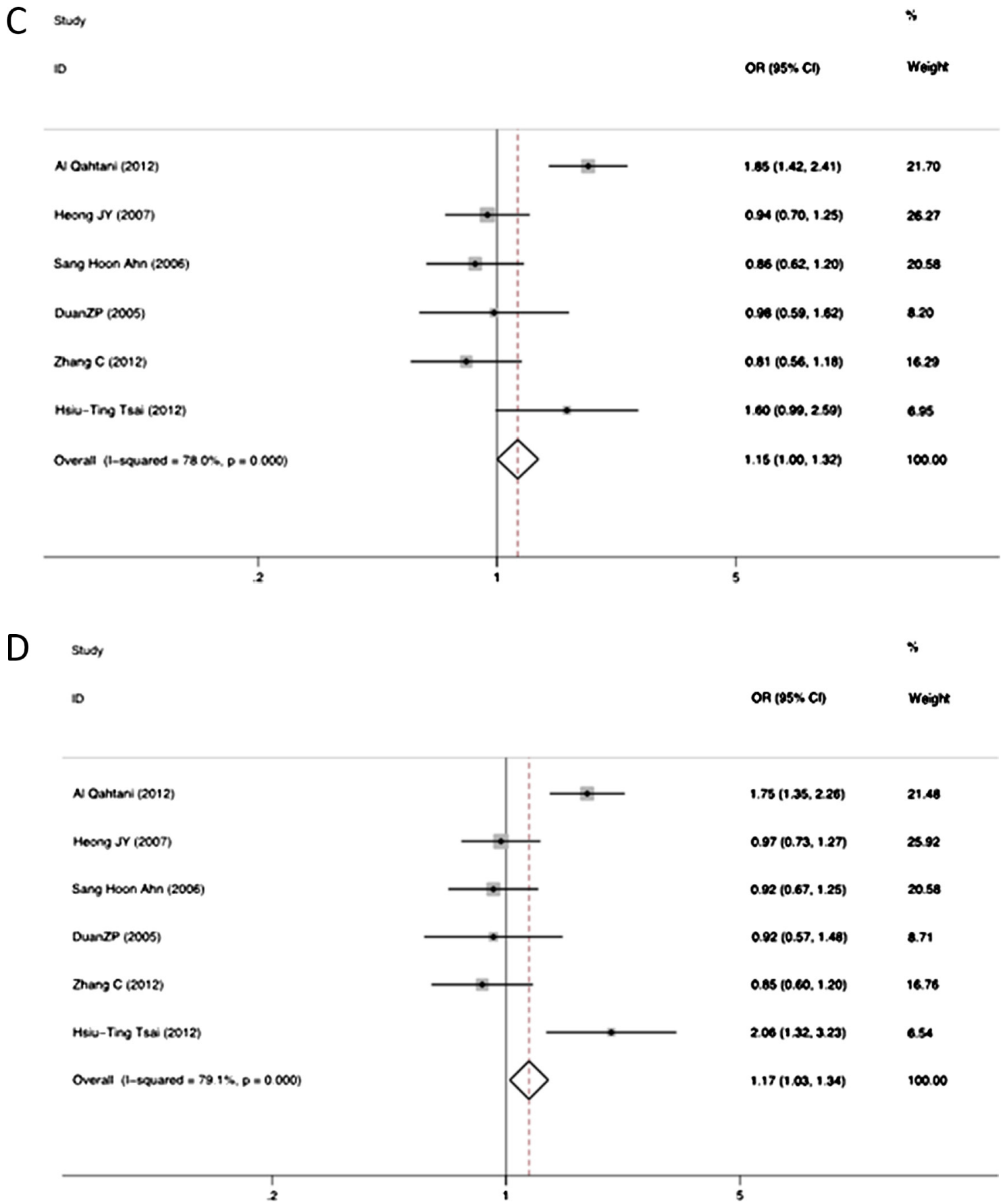

Figure 3: Forest plot of the risk of chronic hepatitis B infection progression related to RANTES gene -403 polymorphism of different genotypes: AA versus GA genotypes (A); AA versus GG genotypes (B); GA versus GG genotypes (C); GA+AA versus combined GG genotypes (D). Black square means value of OR, and the size of the square means inversely proportional to its variance. Horizontal line means $95 \%$ confidence interval (CI) of OR. Black diamond means pooled results.

host's immune ability to counter HBV infection [22-25]. Recently, chemokines and their receptors that were proved to play an important biological role in immune responses should arise more attention [26, 27].

Previous studies have suggested RANTES as one of the candidate genes in the development of persistent HBV infection. The RANTES-CCR5 pathway have shed some light on viral clearance mechanisms, such as with hepatitis C virus [28, 29] and West Nile virus [30]. Studies have demonstrated that it plays an important role in sustaining CD8 T cell responses during the chronic infection $[31,32]$. The mechanism of virus clearance is largely unknown and 
Table 2: Subgroup analyses by ethnicity about association between $R A N T E S$ gene -403 A/G polymorphism and susceptibility to chronic HBV infection

\begin{tabular}{|c|c|c|c|c|c|c|c|}
\hline \multirow{2}{*}{ Genotype } & \multirow{2}{*}{ Ethnicity } & \multirow{2}{*}{ Cases } & \multirow{2}{*}{ Controls } & \multirow{2}{*}{ OR $(95 \% C I)$} & \multirow{2}{*}{$P$} & \multicolumn{2}{|c|}{ Heterogeneity } \\
\hline & & & & & & df ( $P$-value $)$ & $I^{2}(\%)$ \\
\hline \multirow[t]{2}{*}{$\mathrm{A} / \mathrm{G}$} & Caucasian & $304 / 1001$ & $383 / 1267$ & $1.68(1.38,2.04)$ & $<0.001$ & $1(0.96)$ & 97 \\
\hline & Asian & $1661 / 2507$ & $1465 / 2463$ & $1.05(0.96,1.16)$ & 0.27 & $5(0.002)$ & 74 \\
\hline \multirow[t]{2}{*}{ AG/ GG } & Caucasian & $230 / 240$ & $155 / 299$ & $1.85(1.42,2.41)$ & $<0.001$ & 0 & \\
\hline & Asian & $666 / 543$ & $711 / 622$ & $0.96(0.81,1.13)$ & 0.59 & $4(0.24)$ & 28 \\
\hline \multirow[t]{2}{*}{$\mathrm{AA} / \mathrm{GG}$} & Caucasian & $14 / 240$ & $19 / 299$ & $0.92(0.45,1.87)$ & 0.81 & 0 & \\
\hline & Asian & $230 / 543$ & $204 / 622$ & $1.16(0.92,1.46)$ & 0.21 & $4(0.0003)$ & 81 \\
\hline \multirow[t]{2}{*}{$\mathrm{AG}+\mathrm{AA} / \mathrm{GG}$} & Caucasian & $244 / 240$ & $174 / 299$ & $1.75(1.35,2.26)$ & $<0.001$ & & \\
\hline & Asian & $896 / 543$ & $915 / 622$ & $1.01(0.87,1.18)$ & 0.87 & $4(0.02)$ & 65 \\
\hline
\end{tabular}

Table 3: Subgroup analyses by controls types about association between $R A N T E S$ gene -40 A/G polymorphism and susceptibility to chronic HBV infection

\begin{tabular}{|c|c|c|c|c|c|c|c|}
\hline \multirow{2}{*}{ Genotype } & \multirow{2}{*}{ Control types } & \multirow{2}{*}{ Cases } & \multirow{2}{*}{ Controls } & \multirow{2}{*}{ OR $(95 \% C I)$} & \multirow{2}{*}{$P$} & \multicolumn{2}{|c|}{ Heterogeneity } \\
\hline & & & & & & df ( $P$-value $)$ & $I^{2}(\%)$ \\
\hline \multirow[t]{3}{*}{$\mathrm{A} / \mathrm{G}$} & SR & $1523 / 2474$ & $1142 / 1924$ & $0.93(0.84,1.03)$ & 0.15 & $4(0.0003)$ & 81 \\
\hline & $\mathrm{HC}$ & $920 / 1712$ & $706 / 1806$ & $1.22(1.08,1.39)$ & 0.002 & $4(0.0004)$ & 80 \\
\hline & Overall & $1965 / 3508$ & $1848 / 3730$ & $1.04(0.96,1.13)$ & 0.34 & $7(<0.001)$ & 87 \\
\hline \multirow[t]{3}{*}{ AG/GG } & SR & $554 / 437$ & $370 / 266$ & $0.91(0.74,1.11)$ & 0.36 & $2(0.96)$ & 0 \\
\hline & $\mathrm{HC}$ & $600 / 556$ & $496 / 655$ & $1.29(1.09,1.54)$ & 0.004 & $4(0.001)$ & 78 \\
\hline & Overall & $896 / 783$ & $866 / 921$ & $1.15(1.00,1.32)$ & 0.05 & $5(0.0004)$ & 78 \\
\hline \multirow[t]{3}{*}{$\mathrm{AA} / \mathrm{GG}$} & SR & $194 / 437$ & $118 / 266$ & $1.02(0.77,1.34)$ & 0.89 & $2(0.87)$ & 0 \\
\hline & $\mathrm{HC}$ & $160 / 556$ & $105 / 655$ & $1.24(0.92,1.66)$ & 0.16 & $4(0.0004)$ & 80 \\
\hline & Overall & $244 / 783$ & $223 / 921$ & $1.13(0.91,1.41)$ & 0.26 & $5(0.0007)$ & 76 \\
\hline \multirow[t]{3}{*}{$\mathrm{AG}+\mathrm{AA} / \mathrm{GG}$} & SR & $748 / 437$ & $488 / 266$ & $0.94(0.77,1.13)$ & 0.5 & $2(0.94)$ & 0 \\
\hline & $\mathrm{HC}$ & $760 / 556$ & $601 / 655$ & $1.32(1.12,1.56)$ & 0.001 & $4(0.0009)$ & 79 \\
\hline & Overall & $1089 / 921$ & $1140 / 783$ & $0.85(0.75,0.97)$ & 0.02 & $5(0.0002)$ & 79 \\
\hline
\end{tabular}

SR: spontaneously recovered; HC: healthy; OR: odds ratio; CI: confidence interval; df: degrees of freedom.

needs to be solved. To date, there were a series of RANTES polymorphisms been reported, including $-403 \mathrm{~A} / \mathrm{G},-28 \mathrm{C} /$ $\mathrm{G}$, intronic variant $I N T 1.1 \mathrm{~T} / \mathrm{C}$ and $524 \mathrm{~T} / \mathrm{C}$ [11-14, 1720]. They were involved in viral and non-viral diseases, such as AIDS, tuberculosis, type-1 diabetes, coronary artery disease, systemic lupus [33-37]. Different RANTES polymorphisms have different effects on the risk of HBV infection. The conclusions were inconsistent throughout different populations and studies [11-14, 17-20]. Relevant meta-analyses reported that the RANTES $-28 \mathrm{G}$ allele may be beneficial to the resistance to HIV-1 infection among Asians [38, 39].

Eight studies were included in this meta-analysis based on standardized search strategy, which demonstrated that RANTES -403A/G polymorphism has significant association with the susceptibility to persistent HBV infection among Caucasians in allelic and genotypic models. Subgroup analysis by control types showed that RANTES -403A allele might be the risk factor of $\mathrm{HBV}$ infection when compared to healthy controls but not to the SR controls. When combined the cases and SRs and compared them with the healthy controls we found there was also a significant difference in allelic model.

Subgroup analysis by ethnicity revealed a significant association between the RANTES $-403 \mathrm{~A} / \mathrm{G}$ polymorphism and $\mathrm{HBV}$ infection in the Caucasian population but not in the Asian population. The controversial results might come from the variations of ethnicity, sample size, and haplotypes. When stratified by different control groups, the allele was a risk factor compared to the healthy group, 
instead of the SR control group. We inferred that RANTES $-403 \mathrm{~A} / \mathrm{G}$ gene polymorphism may be associated to HBV infection, instead of virus clearance. It was demonstrated that RANTES -403A was associated with the susceptibility to HBV infection, but in the case of clearance progression, other factors need to be explored.

Although meta-analysis is a predominant statistical method, there are still some limitations. Firstly, there was a significant heterogeneity in our study. Secondly, only eight studies were collected and as few as six had specific genotypic data. Insufficient sample size may cause some deviation in data analysis. Therefore, additional studies are needed for further investigation. Thirdly, some unpublished negative results, have not been included. Lastly, we only analyzed the association between $-403 \mathrm{~A} / \mathrm{G}$ and $\mathrm{HBV}$ infection without taking account of relevant environmental factors, such as alcohol consumption and smoking. Geneenvironment interaction may be an important risk factor for the HBV infection, therefore to analyze the interaction may be essential. In the present study, we were unable to perform such analysis due to insufficient data regarding environmental factors in all included studies.

In conclusion, this meta-analysis demonstrated that there was no significant difference between RANTES $-403 \mathrm{~A} / \mathrm{G}$ gene polymorphism and the outcome of persistent $\mathrm{HBV}$ infection. But according to the subgroup analyses, the A allele plays a risk role in HBV infected patients in the Caucasian population. Further studies are needed to verify the this association.

\section{MATERIALS AND METHODS}

\section{Search strategy}

Literature search was performed by two independent researchers in PubMed/MEDLINE (last updated on 1 January 2017), CNKI (last updated on 1 January 2017) using the following keywords: ('CCL5' or 'chemokine ligand 5' or 'RANTES' or 'regulated upon activation normal $\mathrm{T}$ cell expressed and secreted') and ('HBV' or 'hepatitis B' or 'liver disease' or 'chronic hepatitis B virus') and ('polymorphism' or 'gene polymorphisms' or 'gene mutation' or 'gene variants'). No language restrictions were used in the search. Consensuses on controversial issues were reached through consultation between two researchers, or with our supervisor (Zheng Zeng).

\section{Criteria of inclusion and exclusion}

The inclusion criteria were as follows: (a) evaluating the relationship between RANTES -403A/G gene polymorphisms and HBV infection; (b) case-control studies; (c) containing abundant genotype data to calculate the odds ratios (ORs) with 95\% confidence intervals (CIs); (d) full-text; (e) human studies; (f) using the following diagnostic criteria: patients with the serum hepatitis $B$ surface antigen (HBsAg) positive for $\geq 6$ months were diagnosed as persistent $\mathrm{HBV}$ infection; individuals with $\operatorname{HBsAg}(-)$, anti-HBc(-) and anti-HBs(-) were defined as

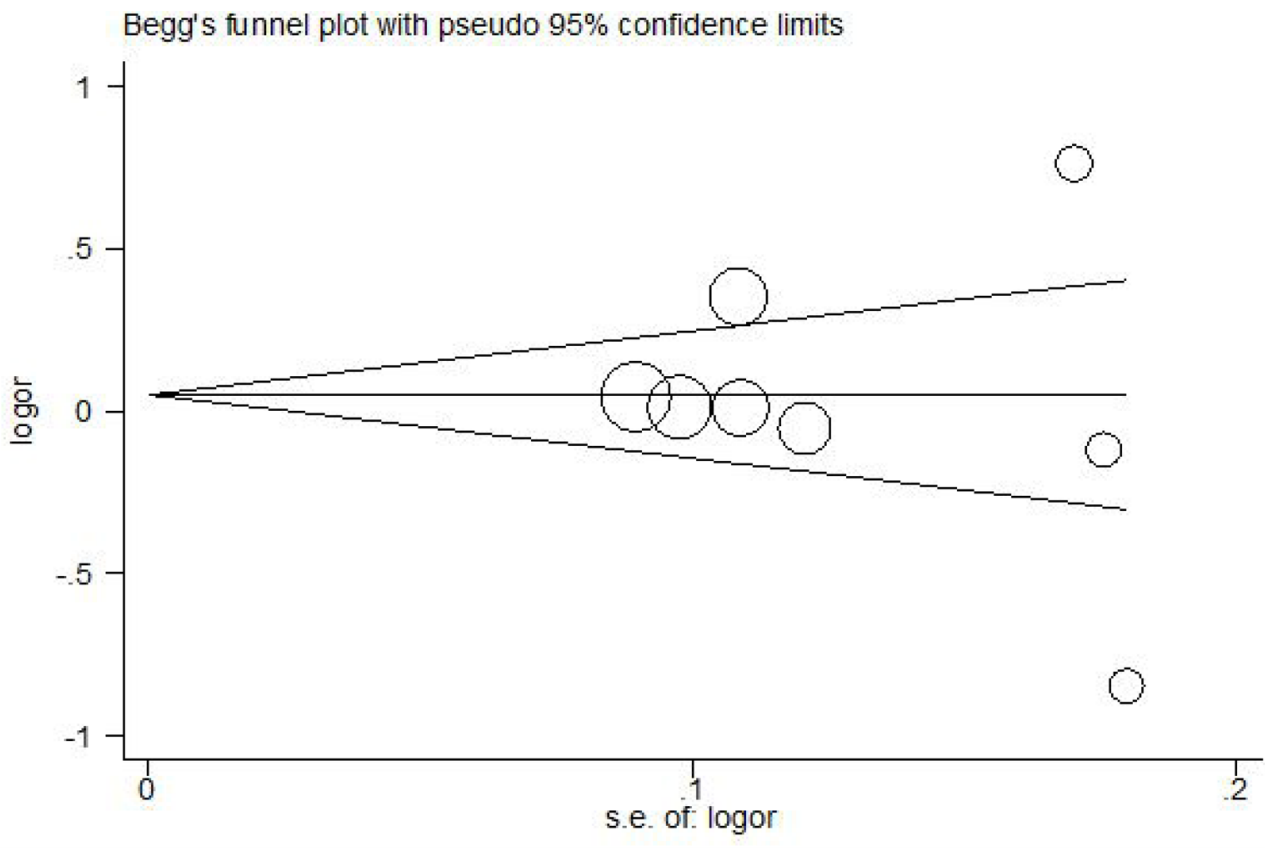

Figure 4: Funnel plot association between RANTES -403A/G polymorphism and chronic HBV infection. Log OR means nature logarithm of OR (odds ratio). Horizontal line means the summary estimate, while the sloping lines mean the expected 95\% confidence interval. Egger's test $p=0.679$. 
health controls (HC); individuals with $\mathrm{HBsAg}(-)$, anti$\mathrm{HBc}(+)$, and anti-HBs(+) were defined spontaneously recovered (SR) controls. The criteria of excluding studies were: (a) the data of the studies were overlapped; (b) no full-text; (c) not a case-control study; (d) not in line with the diagnostic criteria.

In the meantime, we applied Newcastle-Ottawa Quality Assessment Scale (NOS) to assess the quality of all the included case-control studies. Studies with low quality ( $<5$ stars) were excluded.

\section{Data extraction}

The following characteristics were selected from each study: first author's name, year of publication, country and ethnicity of the study population, clinical subtype, numbers of the cases and controls, genotyping methods, sex of the cases and controls, mean age of the cases and controls and the HWE test results. The control groups included healthy individuals (HC) and spontaneous recovered individuals (SR). The case group included all clinical subtypes, such as asymptomatic patients, patients with chronic hepatitis B, liver cirrhosis (LC), or hepatocellular carcinoma (HCC).

\section{Statistical analysis}

The odds ratios (ORs) and the 95\% confidence intervals (CIs) were calculated to assess the relationship between RANTES -403 gene polymorphism and chronic hepatitis $\mathrm{B}$ according to gene allele and genotype: the allelic model (A allele versus $G$ allele), the homozygous model (AA versus GG), the heterozygous model (AA versus GA), the dominant model (GA+AA versus GG). Subgroup analyses were also performed based on clinical control group types and ethnicities. Heterogeneity was estimated by Cochrane's $Q$-test and $I^{2}$ measurement, which means the proportion of variability across studies is due to heterogeneity rather than by chance. $I^{2}>50 \%$ indicated a significant heterogeneity [15] and the random-effects model would be applied. Otherwise, the fixed-effects model would be applied. The quality and reliability of this meta-analysis were evaluated by sensitivity analysis through excluding one study each time. The publication bias was assessed by the Egger's test and funnel plots [16]. All Quantitative analysis was performed using Stata 11.0 software (StataCorp LP, College Station, TX, USA).

\section{Abbreviations}

CCR5: CC receptor 5; CI: confidence interval; DC: dendritic cell; HC: healthy control; HCC: hepatocellular carcinoma; HBsAg: hepatitis B surface antigen; HBV: hepatitis B virus; HWE: Hardy-Weinberg equilibrium; LC: liver cirrhosis; OR: Odds ratio; SR: spontaneous recovered.

\section{ACKNOWLEDGMENTS AND FUNDING}

The project has been supported by ZZ research grant from International Science \& Technology Cooperation Program of China (No. 2014DFR31200), National Nature Science Foundation of China (Grant No.30671855) and federal funds from the National Cancer Institute, National Institute of Health, USA, under Contract No. N01-CO-12400.

The content of this publication does not necessarily reflect the views of policies of the Department of the Health and Human Service, nor does mention of trade names, commercial products or organizations imply endorsement by the U.S. Government. We would also like to sincerely acknowledgements all individuals who contributed to this study.

\section{CONFLICTS OF INTEREST}

The authors have no conflicts of interest relevant to this article to disclose.

\section{REFERENCES}

1. Michel ML, Mancini-Bourgine M. Therapeutic vaccination against chronic hepatitis B virus infection. J Clin Virol. 2005; 34:S108-114.

2. Juszczyk J. Clinical course and consequences of hepatitis B infection. Vaccine. 2000; 18:S23-25.

3. Huang Y, Lok AS. Viral factors and outcomes of chronic HBV infection. Am J Gastroenterol. 2011; 106:93-95.

4. Pan CQ, Zhang JX. Natural History and Clinical Consequences of Hepatitis B Virus Infection. Int J Med Sci. $2005 ; 2: 36-40$.

5. Appay V, Rowland-Jones SL. RANTES: a versatile and controversial chemokine. Trends Immunol. 2001; 22:83-87.

6. O'Neill DW, Adams S, Bhardwaj N. Manipulating dendritic cell biology for the active immunotherapy of cancer. Blood. 2004; 104:2235-2246.

7. Ma K, Xu W, Shao X, Yanyue, Hu L, Xu H, Yuan Z, Zheng $\mathrm{X}$, Xiong S. Coimmunization with RANTES plasmid polarized Th1 immune response against hepatitis B virus envelope via recruitment of dendritic cells. Antiviral Res. 2007; 76:140-149.

8. Ahmadabadi BN, Hassanshahi G, Khoramdelazad H, Mirzaei V, Sajadi SM, Hajghani M, Khodadadi H, Pourali R, Arababadi MK, Kennedy D. Downregulation of CCR5 expression on the peripheral blood CD8+ T cells of southeastern Iranian patients with chronic hepatitis B infection. Inflammation. 2013; 36:136-140.

9. Zhang $\mathrm{K}, \mathrm{Xu} \mathrm{QH}$, Chen LB, Shu X, Chen N, Li G. [Correlation of serum chemokine RANTES level with serum biochemical indices, HBeAg and HBV DNA load in patients with chronic hepatitis B]. [Article in Chinese]. Zhonghua Shi Yan He Lin Chuang Bing Du Xue Za Zhi. 2009; 23:188-190. 
10. Wei XQ, Wen ZF, Zheng FP, Yao JL. [Changes of RANTES levels in livers of patients with chronic hepatitis B: the clinical significance and the possible mechanisms]. [Article in Chinese]. Zhonghua Gan Zang Bing Za Zhi. 2007; 15:585-588.

11. Duan ZP, Zhao XY, Huang DZ, He LX, Chen Y, Zhao CH, Zheng BJ. RANTES gene single nucleotide polymorphisms and expression in patients with chronic hepatitis B virus infection. Chin Med J (Engl). 2005; 118:909-914.

12. Ahn SH, Kim do Y, Chang HY, Hong SP, Shin JS, Kim YS, Kim H, Kim JK, Paik YH, Lee KS, Chon CY, Moon YM, Han KH. Association of genetic variations in CCR5 and its ligand, RANTES with clearance of hepatitis $\mathrm{B}$ virus in Korea. J Med Virol. 2006; 78:1564-1571.

13. Al-Qahtani A, Alarifi S, Al-Okail M, Hussain Z, Abdo A, Sanai F, Al-Anazi M, Khalaf N, Al-Humaidan H, Al-Ahdal $\mathrm{M}$, Almajhdi FN. RANTES gene polymorphisms $(-403 \mathrm{G}>\mathrm{A}$ and $-28 \mathrm{C}>\mathrm{G}$ ) associated with hepatitis B virus infection in a Saudi population. Genet Mol Res. 2012; 11:855-862.

14. Thio CL, Astemborski J, Thomas R, Mosbruger T, Witt MD, Goedert JJ, Hoots K, Winkler C, Thomas DL, Carrington M. Interaction between RANTES promoter variant and CCR5Delta32 favors recovery from hepatitis B. J Immunol. 2008; 181:7944-7947.

15. Jackson D, White IR, Riley RD. Quantifying the impact of between-study heterogeneity in multivariate meta-analyses. Stat Med. 2012; 31:3805-3820.

16. Macaskill P, Walter SD, Irwig L. A comparison of methods to detect publication bias in meta-analysis. Stat Med. 2001; 20:641-654.

17. Cheong JY, Cho SW, Choi JY, Lee JA, Kim MH, Lee JE, Hahm KB, Kim JH. RANTES, MCP-1, CCR2, CCR5, CXCR1 and CXCR4 gene polymorphisms are not associated with the outcome of hepatitis B virus infection: results from a large scale single ethnic population. J Korean Med Sci. 2007; 22:529-535.

18. Zhang C, Shan KR, He Y, Wang CJ, Zhang T, Li Y, Deng J, Li LJ, Ouyang K, Guan ZZ. [Study on the association between RANTES-403G/A as well as $-28 \mathrm{C} / \mathrm{G}$ gene polymorphism and their susceptibility to the hepatitis $\mathrm{B}$ virus infections in Dong and Han ethnicities in Guizhou, China]. [Article in Chinese]. Zhonghua Liu Xing Bing Xue Za Zhi. 2012; 33:1279-1282.

19. Park BL, Kim YJ, Cheong HS, Kim LH, Choi YH, Lee HS, Shin HD. Association of common promoter polymorphisms of MCP1 with hepatitis B virus clearance. Exp Mol Med. 2006; 38:694-702.

20. Tsai HT, Yang SF, Chen DR, Chan SE. CCL5-28, CCL5403, and CCR5 genetic polymorphisms and their synergic effect with alcohol and tobacco consumptions increase susceptibility to hepatocellular carcinoma. Med Oncol. 2012; 29:2771-2779.

21. Fattovich G, Bortolotti F, Donato F. Natural history of chronic hepatitis B: special emphasis on disease progression and prognostic factors. J Hepatol. 2008; 48:335-352.
22. Motavaf M, Safari S, Alavian SM. Interleukin 18 gene promoter polymorphisms and susceptibility to chronic hepatitis B infection: a review study. Hepat Mon. 2014; 14:e19879.

23. Lu Y, Wu Z, Peng Q, Ma L, Zhang X, Zhao J, Qin X, Li S. Role of IL-4 Gene Polymorphisms in HBV-Related Hepatocellular Carcinoma in a Chinese Population. PLoS One. 2014; 9:e110061.

24. Ben-Ari Z, Mor E, Papo O, Kfir B, Sulkes J, Tambur AR, Tur-Kaspa R, Klein T. Cytokine gene polymorphisms in patients infected with hepatitis B virus. Am J Gastroenterol. 2003; 98:144-150.

25. Zhang PA, Li Y, Xu P, Wu JM. Polymorphisms of interleukin-1B and interleukin-1 receptor antagonist genes in patients with chronic hepatitis B. World J Gastroenterol. 2004; 10:1826-1829.

26. Rossi D, Zlotnik A. The biology of chemokines and their receptors. Annu Rev Immunol. 2000; 18:217-242.

27. Epstein FH, Luster AD. Chemokines-chemotactic cytokines that mediate inflammation. N Engl J Med. 1998; 338:436-445.

28. Zeremski M, Hooker G, Shu MA, Winkelstein E, Brown Q, Des Jarlais DC, Tobler LH, Rehermann B, Busch MP, Edlin $\mathrm{BR}$, Talal AH. Induction of CXCR3- and CCR5-associated chemokines during acute hepatitis $\mathrm{C}$ virus infection. J Hepatol. 2011; 55:545-553.

29. Soo HM, Garzino-Demo A, Hong W, Tan YH, Tan YJ, Goh P, Lim SG, Lim SP. Expression of a full-length hepatitis C virus cDNA up-regulates the expression of $\mathrm{CC}$ chemokines MCP-1 and RANTES. Virology. 2002; 303:253-277.

30. Lim JK, McDermott DH, Lisco A, Foster GA, Krysztof D, Follmann D, Stramer SL, Murphy PM. CCR5 deficiency is a risk factor for early clinical manifestations of West Nile virus infection but not for viral transmission. J Infect Dis. 2010; 201:178-185.

31. Crawford A, Angelosanto JM, Nadwodny KL, Blackburn $\mathrm{SD}$, Wherry EJ. A role for the chemokine RANTES in regulating $\mathrm{CD} 8 \mathrm{~T}$ cell responses during chronic viral infection. PLoS Pathog. 2011; 7:e1002098.

32. Samson M, Labbe O, Mollereau C, Vassart G, Parmentier M. Molecular cloning and functional expression of a new human CC-chemokine receptor gene. Biochemistry. 1996; 35:3362-3367.

33. Jamali Z, Nazari M, Khoramdelazad H, Hakimizadeh E, Mahmoodi M, Karimabad MN, Hassanshahi G, Rezaeian M, Balaei P, Darakhshan S, Poor NM. Expression of CC chemokines CCL2, CCL5, and CCL11 is associated with duration of disease and complications in type-1 diabetes: a study on Iranian diabetic patients. Clin Lab. 2013; 59:993-1001.

34. Cui K, Ge XY, Ma HL. Association of the G403A polymorphism in the RANTES gene with coronary artery disease: a meta-analysis. Genet Mol Res. 2013; 12:3912-3918. 
35. Bidyalaxmi Devi L, Bhatnagar A, Wanchu A, Sharma A. A study on the association of autoantibodies, chemokine, and its receptor with disease activity in systemic lupus erythematosus in North Indian population. Rheumatol Int. 2013; 33:2819-2826.

36. Liu H, Chao D, Nakayama EE, Taguchi H, Goto M, Xin X, Takamatsu JK, Saito H, Ishikawa Y, Akaza T, Juji T, Takebe Y, Ohishi T, et al. Polymorphism in RANTES chemokine promoter affects HIV-1 disease progression. Proc Natl Acad Sci U S A. 1999; 96:4581-4585.

37. An P, Nelson GW, Wang L, Donfield S, Goedert JJ, Phair J, Vlahov D, Buchbinder S, Farrar WL, Modi W, O’Brien
SJ, Winkler CA. Modulating influence on HIV/AIDS by interacting RANTES gene variants. Proc Natl Acad Sci U S A. 2002; 99:10002-10007.

38. Alqumber MA, Mandal RK, Haque S, Panda AK, Akhter N, Ali A. A genetic association study of CCL5 -28 C $>\mathrm{G}$ (rs2280788) polymorphism with risk of tuberculosis: a meta-analysis. PLoS One. 2013; 8:e83422.

39. Gong Z, Tang J, Xiang T, Zhang L, Liao Q, Liu W, Wang Y. Association between regulated upon activation, normal T cells expressed and secreted (RANTES) - 28C/G polymorphism and susceptibility to HIV-1 infection: a meta-analysis. PLoS One. 2013; 8:e60683. 